\title{
Book Review - The burden of history: Namibia and Germany from Colonialism to postcolonialism
}

\author{
Heike Becker
}

Reinhart Kössler, Namibia and Germany: Negotiating the Past (Windoek and Münster, UNAM Press and Westfälisches Dampfboot Verlag, 2015), xiii + 378 pp., paperback, €39.90, ISBN 978-99916-42-09-3.

When former German Foreign Minister Joseph 'Joschka' Fischer visited Windhoek in October 2003, he went on record to say that there would be no apology that might give grounds for reparations for the first genocide of the 2oth century, which was committed by German colonial troops in Namibia in 1904-1908. Fischer's rather undiplomatic words are indicative of the intense and heated historical and present relations between Germany and her erstwhile colony.

Reinhart Kössler's new book examines the transnational relations between the two countries in the postcolonial setting. He presents multiple perspectives on the genocide and its memory, starting from the violent colonial relationship and its consequences for a racist ideology, which prepared the ground for the genocide. The theme is then followed through to the present, where he juxtaposes the prominent attention paid to Germany and the German-Namibian past in Namibia with the shallow consideration that the common history has been given in Germany. Kössler also shows that the continued presence of a small but economically powerful German-speaking community in Namibia presents particular challenges for negotiating the image of the past.

The book has been divided into three parts. Part 1 is the longest, titled 'The Burden of History', comprising six chapters. It opens with renditions of German colonial history from German and various Namibian perspectives. Kössler thus sets out to understand the conceptual registers of various groups of actors. He shows how the events of the early 2oth century have shaped historical narratives, and that many people from southern and central Namibia feel that their historical experiences have been marginalised in the dominant Namibian narrative, which revolves around the nationalist movement of the second half of the 2oth century. The following chapters are concerned with German colonialism and the genocide, and its impact on colonial amnesia in Germany. Kössler also develops multiple perspectives on Germany and its identification in memory politics in Namibia. This theme is advanced in the part's final chapter, through the contested meanings of a colonial memorial in Windhoek; the statue of the Windhoek Rider (Reiterdenkmal) sat in a prominent hill-top position in the cityscape until its removal in 2010, when it made way for a statue of Nujoma in front of the North Korean-built Independence Memorial Museum. 
The three chapters of Part 2 elaborate commemorative reconstructions and performances that were constituted in the wake of the genocide. They are based on close-up fieldwork, including conversations and interviews that Kössler conducted with key players, and his participation in annual commemorations of four Herero- and Nama-speaking communities. He presents the proceedings of these commemorations in fascinating detail, describes historical re-enactments, and points out the prominent symbolic role of a heroic war-like past. He shows that the commemorations manifest and reproduce communal 'tradition' and, most significantly, assert each community's claim to a rightful place in the history of anti-colonial resistance in Namibia.

Part 3, also divided into three chapters, presents the uneven trajectories of GermanNamibian postcolonial relations since 1990. By looking at changing actor constellations in both Namibia and Germany, Kössler unravels the difficulties of negotiating a painful past transnationally in a postcolonial setting. He delineates the German ducking and diving tactics. In the 1990s, the Namibian German-speakers were the centre of the attention of politicians such as Chancellor Helmut Kohl. Following Fischer's calculated voice, cited above, came the ineffective attempt at an apology delivered by Heidemarie WieczorekZeul, then Germany's Minister of Development Co-operation, during the Herero genocide centenary commemorations in 2004. The same period saw a gradual move by the SWAPO Party of Namibia government to take up the issue, which had hitherto been left to ethnically identified opposition politicians-cum-traditional leaders. The final substantive chapter then takes an in-depth look into what Kössler dubs the 'saga of the skulls'. Skulls of genocide victims had been shipped to academic and medical institutions in Germany and had remained there until, following vigorous campaigning by Namibian committees, some were returned in 2011 and 2014, respectively.

Kössler calls this 'restitution without recognition'. He closes on the sombre note that, 'the main issue, the question of a formal German apology is still pending' (p. 326). This has begun to change, however, since the book went into production. In July 2015, the speaker of the German parliament penned an article in the influential weekly Die Zeit, in which he acknowledged that the war crimes committed by the colonial command in Namibia indeed constituted genocide. This set a process in motion; now official Namibian and German envoys are talking about the way ahead, including reparations.

This monograph challenges Namibia's fragmented history. I have few disagreements, the most significant of which is, perhaps, Kössler's take on the dominant Namibian nationalist narrative of anti-colonial struggles, which, he claims, while neglecting southern and central Namibia, recognised the exiled SWAPO and northern Namibian experiences. My own research in the north contests this claim; many who lived as civilians through the 1966-1989 nationalist liberation war in the northern war zone feel that their experience has not been recognised either. ${ }^{1}$

Coming from a background in Eastern European History and Sociology, Kössler brings to

\footnotetext{
${ }^{1}$ Heike Becker, 'Commemorating Heroes in Windhoek and Eenhana: Memory, Culture and Nationalism in Namibia, 1990-2010', Africa, 81, 4 (2011), pp. 519ff.
} 
this study reading that ranges beyond the usual Africanist canon. This shows in many parts of this deeply knowledgeable book, particularly in the incisive discussion of the lines that lead from colonial genocide in Namibia to the holocaust of the European Jews and other 'undesirables'. Kössler's nuanced argument here goes further than the lines commonly drawn, which emphasise personal continuities between the German colonial army and the Nazis. While he broadly agrees that, 'so much of what took place in GermanSouth-West Africa at the beginning of the twentieth century horribly prefigures the events of the 1940s', ${ }^{2}$ his discussion points out the deep roots of German authoritarian nationalism. Quoting Adorno's famous phrase coined in respect of the Nazi era, he argues that the German colonial past still requires much 'working through' (p. 318). As a veteran of German solidarity activism with southern Africa, Kössler himself has been a significant actor in the campaigns for the recognition of, and apology for, Germany's genocide in Namibia.

This book is essential reading for everyone interested in colonial history and postcolonial memory politics, in Namibia, in Germany, and beyond. ${ }^{2}$ David Olusoga and Casper W. Erichsen, The Kaiser's Holocaust: Germany's Forgotten Genocide and the Colonial Roots of
Nazism (London, Faber and Faber, 2010), p. 361. 